\title{
OPTIMIZATION OF ULTRASONICATED MEMBRANE ANAEROBIC SYSTEM (UMAS) FOR SEWAGE SLUDGE TREATMENT USING RESPONSE SURFACE METHODOLOGY (RSM)
}

\author{
Mazza S. A ${ }^{1}$, Abdurahman H. $\mathbf{N}^{2}$, Said $\mathrm{N}^{3}$, Azwina $Z^{4}$, Mohamed. B. $\mathrm{S}^{5}$ \\ ${ }^{1,2,34}$ Faculty of Chemical and Natural Resources Engineering, University Malaysia Pahang, Malaysia \\ ${ }^{5}$ Faculty of Industrial Sciences and Technology, University Malaysia Pahang, Malaysia
}

\begin{abstract}
Ultrasonicated Membrane Anaerobic System UMAS was successfully used for sewage sludge treatment and biogas production. Central Composite Design and Response Surface Methodology were used to determine the optimum conditions in which UMAS produce a maximum content of methane in the biogas produced. The effects of three variables namely $\mathrm{pH}$, chemical oxygen demand $(C O D)$ and organic loading rate $(O L R)$ on methane content were evaluated individually and interactively. The optimum conditions obtained were $\mathrm{pH} 7.74, \mathrm{COD} 1061.06 \mathrm{Mg} / \mathrm{l}$ and $\mathrm{OLR} 0.90 \mathrm{~kg} / \mathrm{m}^{3} \mathrm{~d}$. The predicted maximum percentage of methane was $89.72 \%$ and confirmed close to RSM result.
\end{abstract}

Keywords: Optimization, Response Surface Methodology, Sewage Sludge, Ultrasonic, Membrane, Anaerobic Digestion. *** $*$

\section{INTRODUCTION}

The treatment of sewage sludge has an important goal to recycle resources without supply of harmful substance to humans or environment. Also, to avoid the deposit sludge on landfill since the degradation of its organic constituents on landfill produces carbon dioxide and methane which recirculates carbon back to the atmosphere and causes global warming. Sewage sludge is produced during wastewater treatment in large amounts. It produced as the single largest residual product of the sewage treatment process. This amount is growing hugely with the increase of wastewater treatment.

Anaerobic digestion is considered a sustainable option for management of organic waste and by-products as it produce renewable energy in the form of biogas and enables recycling of materials, especially nutrients. Simultaneously, it enables controlled stabilization and thus decreased emissions from the treated waste materials [1]. However, the conventional anaerobic system is limited to certain conditions, i.e. it is not feasible for treating low - strength wastewater in cold climate [2]. In addition anaerobic process is slow, long residence time in the reactor, and large reactor's volumes are required. In case of sewage sludge digestion, hydrolysis has been considered to be the rate limiting step in the overall anaerobic digestion [3]. The MBR process is already considered as a viable alternative for many waste treatment challenges and with water quality issues firmly placed into the forefront of public debate, ever tightening discharge standards and increasing water shortages will further accelerate the development of this technology [4]. Membrane bioreactor systems (MBRs) have, over the past ten years, emerged as an effective solution to transforming various wastewaters into high quality effluent suitable for discharge into the environment and increasingly into a reusable product.

Membrane system coupled with anaerobic reactor has been found to be an effective method for sewage sludge treatment. It could provide good effluents since the ultrafiltration system could enhance the anaerobic operation. This appeared in the recognizable biogas produced and sustaining good separation solid/liquid [5]. However such system has the problem of membrane fouling which is should be controlled to maintain good feasibility and high performance. In order to prevent membrane fouling, incorporating ultrasound to anaerobic membrane bioreactor is expected to make good control for membrane fouling [6]. In addition, ultrasound has been proven effective for enhancement of membrane filtration of various solutions such as peptone, whey, milk solution and paper industrial wastewater. Moreover, the offline ultrasound was adopted as a membrane cleaning method for microfiltration of activated sludge [7].

RSM is a collection of mathematical and statistical techniques for experimental design, model development, the evaluation of factors, and the optimization of conditions. Response Surface Methodology allows determination of the optimum conditions and also the analysis of how sensitive the optimum conditions are to variation in experimental variables [8]. The aim of this study was to optimize the UMAS for sewage sludge treatment to identify the optimum conditions at which a maximum percentage of methane could be produced. 


\section{MATERIALS AND METHODS}

The Ultrasonicated membrane anaerobic system (UMAS) was composed of a cross flow ultra-filtration membrane (CUF) apparatus, a centrifugal pump, an anaerobic reactor of effective volume of $50 \mathrm{~L}$ and 6 ultrasonic transducers were bonded to the two sided of the tank chamber and connected to one unit of 250 watts $25 \mathrm{KHZ}$ Crest's Genesis Generator. The UF have molecular weight cut-off (MWCO) of 200,000, a tube diameter of $1.25 \mathrm{~cm}$ and an average pore size of $0.1 \mu \mathrm{m}$. the length of each tube was $30 \mathrm{~cm}$. The maximum operating pressure on the membrane was 55 bars at $70^{\circ} \mathrm{C}$, and the $\mathrm{pH}$ ranged from 2 to 12 . The reactor which made of PVC was covered with aluminum foil to prevent any direct light. The volume of the reactor was $50 \mathrm{~L}$ with inner diameter of $15 \mathrm{~cm}$ and a total height of $100 \mathrm{~cm}$. The operating pressure in this study was maintained between $1.5-2$ bars by manipulating the gate valve at the retentate line after the CUF unit. The sewage sludge was taken from the anaerobic tank in Indah waste water treatment plant in Kuantan, Pahang, Malaysia. The sludge was screened through strainer before being added to the digester to avoid clogging and pump damage. After, daily samples were analyzed to determine the TSS, VSS, COD, BOD, VFAs, Color, Turbidity, Nitrogen and $\mathrm{pH}$ for the Raw feed permeate and from inside the reactor.

\subsection{Analytical Techniques}

The chemical oxygen demand COD for all samples were determined by the dichromate reflux (HACH Water analysis Method). The biochemical oxygen demand (BOD) was determined by analyzing the Oxygen depletion after sample incubation at $20^{\circ} \mathrm{C}$ for 5 days. As described in (the standard method5210B). Digester mixed liquor (reactor content) suspended solids was determined by filtration through a glass fiber filter method. The analytical procedure was the same in the standard methods. The volatile fatty acids were measured by simple titration against $0.02 \mathrm{~N} \mathrm{NaOH}$ and $0.02 \mathrm{~N}_{2} \mathrm{SO}_{4}$. The color was measured using spectrophotometer. The volume of gas was measured daily using J-tube gas analyzer. It is assumed in this method that the biogas produced composed only of two gases $\mathrm{CO}_{2}$ and $\mathrm{CH} 4$. Then sodium hydroxide was absorbing the $\mathrm{CO}_{2}$. The remaining volume is methane gas $\mathrm{CH}_{4}$. The device consisted of a glass- tube connected by a flexible hose to a syringe. The syringe was initially filled with $0.5 \mathrm{M} \mathrm{NaOH}$ solution, the glass tube was inserted into the gas zone inside the reactor where a column of biogas drawn into the glass-tube until a certain mark. Then the end of the tube immediately immersed in water. By manipulating the syringe many times, the $\mathrm{NaOH}$ solution was absorb the carbon dioxide $\mathrm{CO}_{2}$, leading to reduction in the length of the biogas column, then the biogas column was measured again. The percentage of methane in the biogas are calculated using the following equation:

The Final length of gas column The Initial length of the gas column

\subsection{Design of Experiments}

The experimental design was carried out based on Central Composite Design (CCD) with Response Surface Methodology (RSM). It applied for three independent variables each at two levels to fit second order polynomial model. The software Design Expert ${ }^{\circledR}$ version 7.1.6 State- Ease inc. was used. The variables of $\mathrm{pH}$, chemical oxygen demand (COD) and organic loading rate (OLR) and their levels are shown in Table 1.

Table -1: Independent variables of CCD design

\begin{tabular}{|l|l|l|l|}
\hline Name & Units & Low Level & High Level \\
\hline A: $\mathrm{pH}$ & - & 6.5 & 7.78 \\
\hline $\begin{array}{l}\text { B: Chemical } \\
\text { oxygen demand ( } \\
\text { COD) }\end{array}$ & $\mathrm{mg} / \mathrm{l}$ & 144.33 & 1265 \\
\hline $\begin{array}{l}\text { C: Organic loading } \\
\text { rate ( OLR) }\end{array}$ & $\mathrm{kg} / \mathrm{m}^{3} \mathrm{~d}$ & 0.0909 & 0.9519 \\
\hline
\end{tabular}

\section{RESULTS AND DISCUSSION}

\subsection{ANOVA Analysis and Model Fitting}

The experimental results of methane production by CCD with 3 central points and the predicted values are presented in Table 2.

Table -2: Central composite design matrix measured and predicted response of methane prediction.

\begin{tabular}{|l|l|l|l|l|l|}
\hline \multirow{2}{*}{ Run } & \multicolumn{3}{|c|}{ Factors } & \multicolumn{2}{c|}{ Response \% } \\
\cline { 2 - 6 } & A & B & C & Predicted & Actual \\
\hline 1 & 7.18 & 0.52 & 887.77 & 79.32 & 80.05 \\
\hline 2 & 7.18 & 0.52 & 704.66 & 79.15 & 80.96 \\
\hline 3 & 7.18 & 0.52 & 1097.10 & 89.00 & 88.52 \\
\hline 4 & 6.32 & 0.52 & 704.66 & 86.84 & 88.04 \\
\hline 5 & 6.57 & 0.09 & 144.33 & 85.37 & 88.77 \\
\hline 6 & 7.78 & 0.95 & 144.33 & 86.09 & 88.8 \\
\hline 7 & 6.57 & 0.95 & 1265.00 & 82.25 & 81.16 \\
\hline 8 & 7.18 & 0.52 & 704.66 & 83.85 & 83.5 \\
\hline 9 & 7.18 & 0.13 & 704.66 & 83.64 & 84 \\
\hline 10 & 7.18 & 0.09 & 704.66 & 81.14 & 79.55 \\
\hline 11 & 7.03 & 0.52 & 704.66 & 82.63 & 81.22 \\
\hline 12 & 7.18 & 0.52 & 704.66 & 81.09 & 80.55 \\
\hline 13 & 7.78 & 0.09 & 1265.00 & 81.75 & 81.8 \\
\hline
\end{tabular}

Keys: A: pH; B: OLR; C: COD.

The results obtained were analyzed by standard analysis of variance (ANOVA) Table 3. The model F-value of 8.98 implied the model was significant. There is $4.8 \%$ chance that a "Model F-value" this large could occur due to noise. Values of "prob $>F$ " less than 0.05 indicate that the model terms are 
significant. In this case $\mathrm{A}, \mathrm{C}, \mathrm{AB}$ and $\mathrm{A}^{2}$ were significant terms for the model, while $\mathrm{B}, \mathrm{AC}, \mathrm{B}^{2}$ and $\mathrm{C}^{2}$ were found to be insignificant. The design showed insignificant lack of fit (Fvalue 0.21 ) which desirable, related to the pure error and this means there is a $68.90 \%$ chance that lack of fit could have occurred due to noise. On the other hand, the determination coefficient $\mathrm{R}^{2}$ was 0.9642 reasonably closed to 1 which is acceptable. The value of $\mathrm{R}^{2}$ indicates that $96.42 \%$ of the variables fit the response. The effects of variables on methane

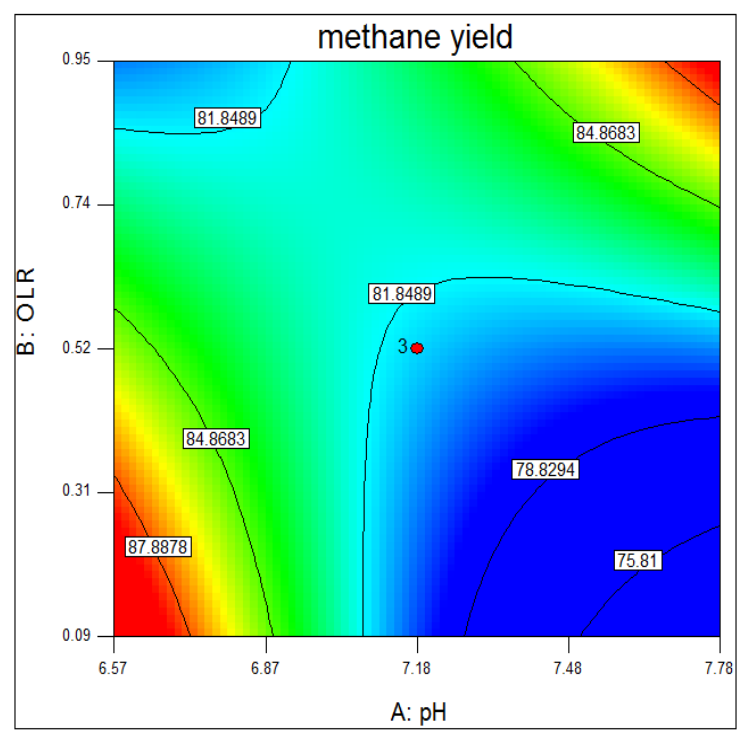

(A)

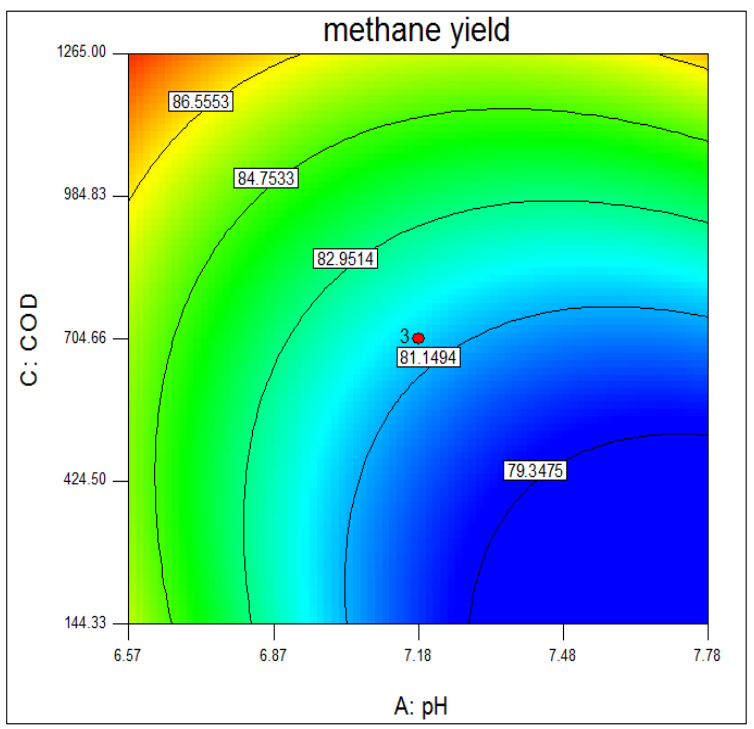

(C) percentage were predicted by Design Expert software and developed regression equation (in terms of coded factors) was as follow:

Methane yield $\%=+81.52-2.41 \mathrm{~A}+1.57 \mathrm{~B}+2.99 \mathrm{C}+6.65 \mathrm{AB}$

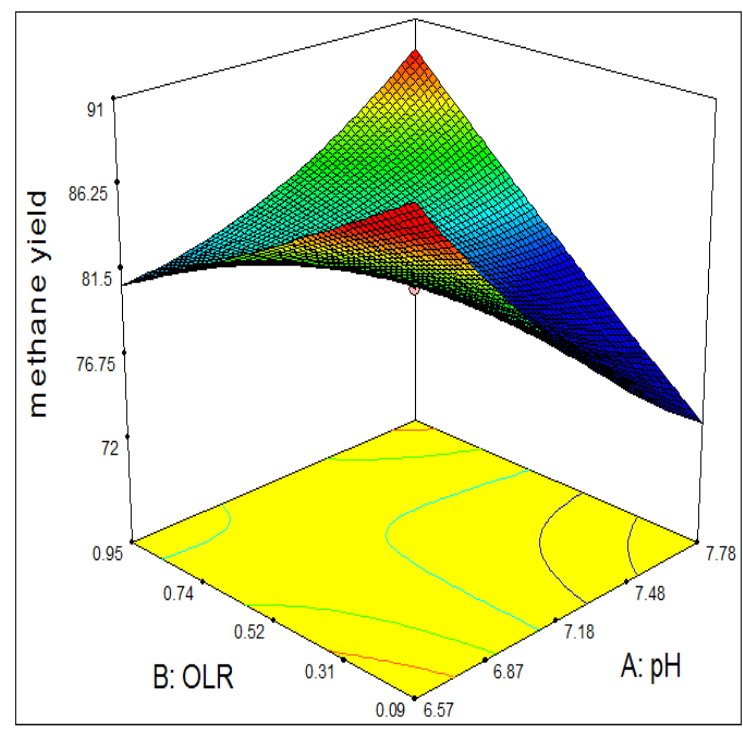

(B)

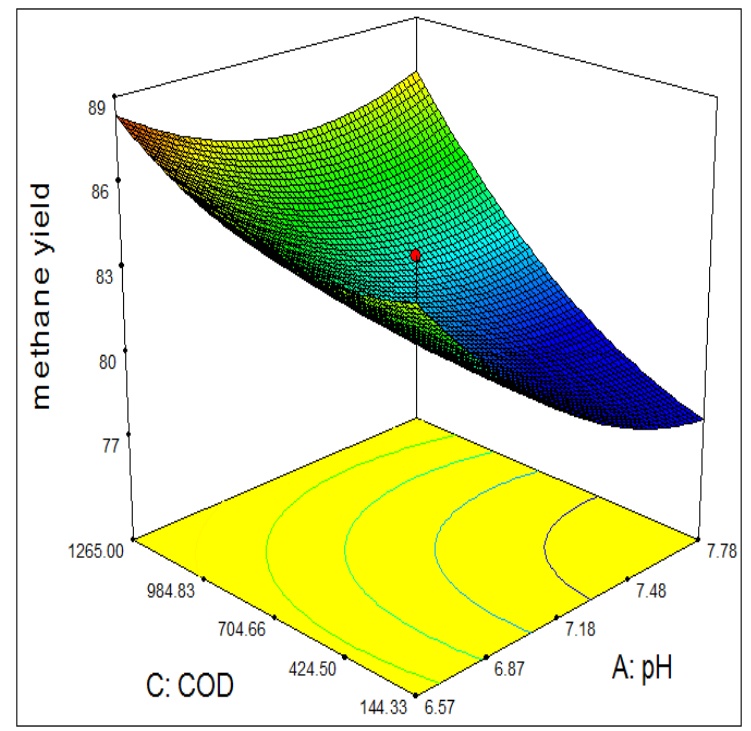

(D) 


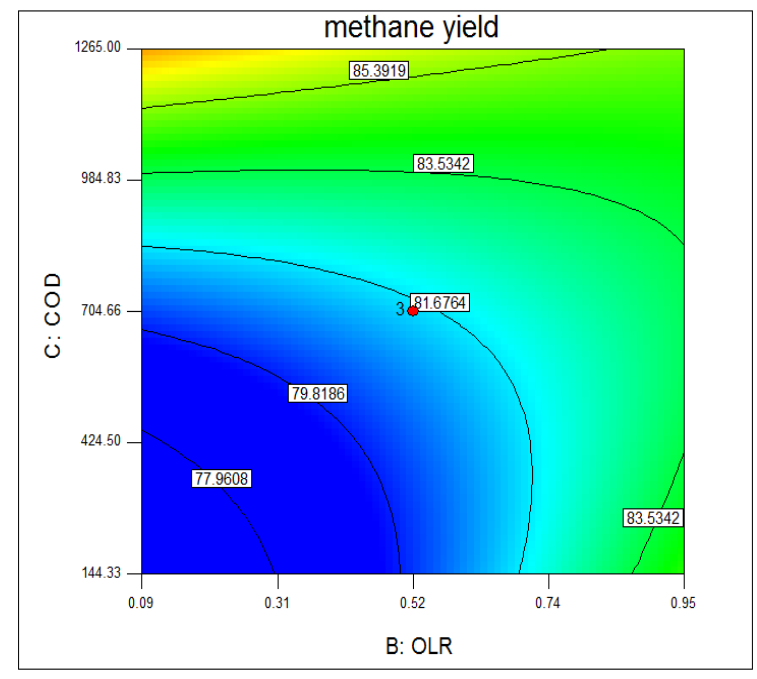

(E)

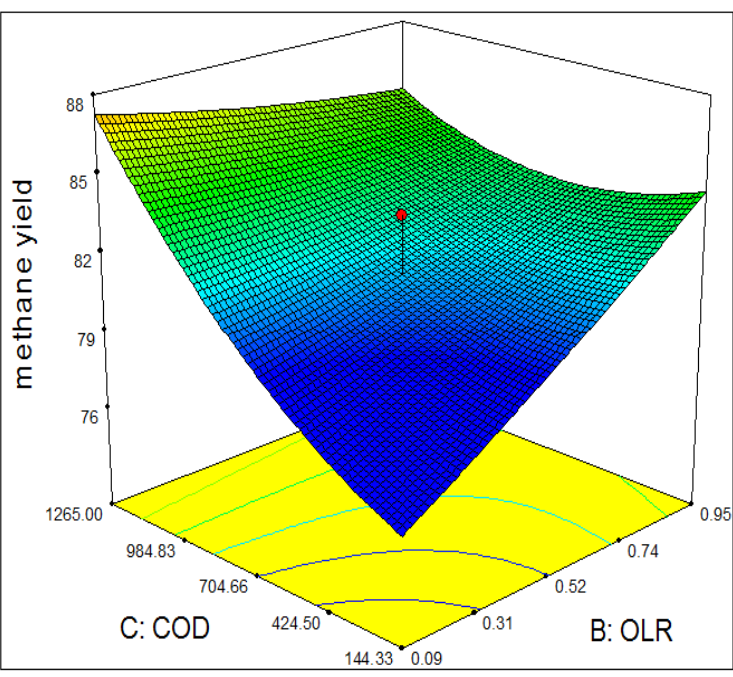

(F)

Fig -1: 3D response surface and contour plots: interactive effects of (A) and (B) varied pH and OLR at COD 1061 mg/l ;(C) and (D) varied $\mathrm{pH}$ and COD at OLR 0./1/d ; (E) and (F) varied OLR and COD at $\mathrm{pH} 7.74$

Table 3: Analysis of variance (ANOVA) for the experimental results of the central composite design

\begin{tabular}{|l|l|l|l|l|l|l|}
\hline Source & Squares & df & $\begin{array}{l}\text { Mean } \\
\text { Square }\end{array}$ & $\begin{array}{l}\text { F- } \\
\text { Value }\end{array}$ & $\begin{array}{l}\text { P-Value } \\
\text { Prob>F }\end{array}$ & \\
\hline Model & 152.34 & 9 & 16.93 & 8.98 & 0.0487 & S \\
\hline A-pH & 23.26 & 1 & 23.26 & 12.34 & 0.0391 & \\
\hline B-OLR & 9.90 & 1 & 9.90 & 5.25 & 0.1058 & \\
\hline C-COD & 35.87 & 1 & 35.87 & 19.03 & 0.0223 & \\
\hline AB & 88.37 & 1 & 88.37 & 46.88 & 0.0064 & \\
\hline AC & 5.96 & 1 & 5.96 & 3.16 & 0.1735 & \\
\hline BC & 13.30 & 1 & 13.30 & 7.06 & 0.0766 & \\
\hline $\mathrm{A}^{2}$ & 18.81 & 1 & 18.81 & 9.98 & 0.0509 & \\
\hline $\mathrm{B}^{2}$ & 0.38 & 1 & 0.38 & 0.20 & 0.6849 & \\
\hline $\mathrm{C}^{2}$ & 15.11 & 1 & 15.11 & 8.02 & 0.0661 & \\
\hline Residual & 5.65 & 3 & 1.88 & & & \\
\hline $\begin{array}{l}\text { Lack of } \\
\text { Fit }\end{array}$ & 0.55 & 1 & 0.55 & 0.21 & 0.6890 & NS \\
\hline
\end{tabular}

Keys: A: pH; B: OLR; C: COD; S: Significant; NS: not Significant.

\subsection{Response Surface Plots}

The optimum level of each variable and the effect of their interactions on methane production were studied by plotting $3 \mathrm{D}$ response surfaces and $2 \mathrm{D}$ contours against any tow independent variables, with third one remained constant (Fig.1). The effects of $\mathrm{pH}$ and OLR interaction on methane yield percentage are presented in Fig.1(A) and Fig.1(B) by 3D and $2 \mathrm{D}$ plots respectively, where COD was selected as center point at $1061.06 \mathrm{mg} / \mathrm{l}$. It can be observed that the methane production was increasing with the $\mathrm{pH}$ decreasing and OLR increasing. It is very important to control the $\mathrm{pH}$ since the methanogenesis bacteria is very sensible to the $\mathrm{pH}$ and it can be inhibited out of the range of 6.5-7.8 $\mathrm{pH}$. The effect of $\mathrm{pH}$ and COD interaction on methane percentage when the OLR maintained at 0.90 is shown in Fig. 1(C) and Fig.1(D), it is clear that the methane increased with less $\mathrm{pH}$ and higher COD. The effect of OLR and COD on methane percentage when the $\mathrm{pH}$ maintained at 7.74 is shown in Fig 1(E) and Fig.1(F). Increasing OLR and COD lead to increase the methane gas production. Generally the methane gas increase with the OLR increase until the acclimatization of sludge became very slow; the acitogenic bacteria dominate in the reactor rather than methanogenic bacteria and the concentration of volatile fatty acids increase. In case illustrated in Fig. 1(A), (B), (D), (E) the methane gas increased but there was no decreasing with OLR increase, this because the OLR was still not very high and the methanogenises still active and no acids yet.

\subsection{Optimization and Verification of the Model}

By using the numerical optimization of Design-Expert 7.1.6 software based on the model proposed, one solution was generated by the software to determine the optimum conditions of the process. The optimum conditions to produce methane yield percentage are realized when the $\mathrm{pH}$ was 7.74 , the organic loading rate was $0.90 \mathrm{kgCOD} / \mathrm{m}^{3} / \mathrm{d}$ and COD was $1061.06 \mathrm{mg} / \mathrm{l}$ According to the results obtained after solving the regression model equation, the maximum predicted methane percentage was $89.72 \%$. In order to verify the model developed, an additional experiment was performed according to the process conditions presented in Table 3, to confirm the optimum result. The actual response obtained is lower than the 
predicted value. According to the percentage error between the actual and predicted value, which was calculated based on equation 2 , the model is acceptable since the error is below

$$
\% \text { Error }=\frac{\text { Residual }}{\text { Actual value }} \times 100
$$

Table -3: Confirmation run of the methane gas percentage

\begin{tabular}{|c|c|c|c|c|c|c|}
\hline A:pH & B:OLR & C:COD & Predicted & Actual & Residual & Error \% \\
\hline 7.5 & 0.893 & 990 & 89.72 & 88.8 & -0.92 & 1.036 \\
\hline
\end{tabular}

\section{CONCLUSIONS}

In summary, statistical optimization method (a central composite design coupled with response surface methodology (RSM)) was successfully employed to obtain the optimum process conditions while the interactions between process variables were demonstrated. The maximum methane percentage was obtained at feed $\mathrm{pH}$ of 7.74, COD of 1061.06 $\mathrm{mg} / \mathrm{l}$ and OLR of $0.90 \mathrm{~kg} / \mathrm{m}^{3} \mathrm{~d}$. ANOVA showed a high $\mathrm{R}^{2}$ value of regression model equation $\left(R^{2}=0.9642\right)$, thus insuring a satisfactory adjustment of second order regression model with the experimental data.

\section{ACKNOWLEDGEMENTS}

The authors acknowledge University Malaysia Pahang for the Graduate Research Scheme GRS No. 120316, and also. we thank Indah Water Company Kauntan Pahang Malaysia for supplying us with the raw sewage sludge.

\section{REFERENCES}

[1]. Luste, S. and Luostarinen, S. 2010. Anaerobic codigestion of meat processing by-products and sewage sludgeeffect of hygienization and organic loading rate. Bioresource Technology. 101:2657-2664..

[2]. Berube, P.R., Hall, E.R. and Sutton, P.M. 2006. Parameters Governing permrate flux in an anaerobic membrane bioreactor treating low-strength municipal wastewaters: literature review, Water Environ. Tes. 78.

[3]. Oh,S.E. 2006. Improvement of anaerobic digestion rate of biosolids in waste activated sludge (WAS) by ultrasonic pretreatment, Environ. Eng. Res. 11: 143-148.

[4]. Cicek, N. 2003. Areview of membrane bioreactors and their potential application in the treatment of agricultural waste water. Canadian Biosystems Engineering. 45: 637-649. [5]. Abdullah, A.G.L., Idris, A., Ahmadun, F.R., Baharin, B.S., Emby, F. Noor, M.J. and Nour,A.H. 2005. A kinetic study of a membrane anaerobic reactor (MAR) for treatment of sewage sludge, Desalination 183: 439-445.

[6]. Xu, M., Wen, X., Yu,Z. and Huang,X. 2011. A hybrid anaerobic membrane bioreactor coupled with online ultrasonic equipment for digestion of waste activated sludge, Bioresourse Technology. 102: 5617-5625.
[7]. Xu, M., Wen, X., Huang, X., Yu, Z. and Zhu, M. 2013. Mechanism of membrane fouling controlled by online ultrasound in an anaerobic membrane bioreactor for digestion of waste activated sludge. Journal of membrane science. 445:119-126.

[8]. Rastegar, S.O., Mousavi, S.M., Shojaosadati, S.A. and Sheibani, S. 2011. Optimization of petroleum refinery effluent treatment in a UASB reactor using response surface methodology. Journal of Hazardous Materials. 197: 26-32. waste water. Canadian Biosystems Engineering. 45: 637-649. 